\title{
Is Theism Compatible With Moral Error Theory?
}

\begin{abstract}
This paper considers whether theism is compatible with moral error theory. This issue is neglected, perhaps because it is widely assumed that these views are incompatible. I argue that this is mistaken. In so doing, I articulate the best argument for thinking that theism and moral error theory are incompatible. According to it, these views are incompatible because theism entails that God is morally good, and moral error theory entails that God is not. I reject this argument. Since it is the best argument for thinking that theism and moral error theory are incompatible, I conclude that these views are compatible: one can coherently accept both views.
\end{abstract}

Keywords: theism, moral error theory, divine goodness, perfect being theology, moral properties.

\section{Theism and Moral Error Theory}

This paper considers whether theism and moral error theory are compatible. So we should start by clarifying what these views are.

Theism is the view that God exists. By 'God', I mean an incorporeal, eternal, omnipotent, omniscient, perfectly loving being, who is the creator and sustainer of all things. In other words, I mean the God of traditional western monotheism. ${ }^{1}$

Moral error theory, by contrast, is the view that all moral judgements are false. I take this view to consist of three theses:

(1) There are no (instantiated) moral properties.

(2) Moral judgements are beliefs that ascribe moral properties.

(3) If a belief ascribes a property to an object that the object does not have, then the belief is false.

Each of these theses requires some comment. ${ }^{2}$

(1) is an ontological thesis about moral properties, where moral properties are "ontologically committing" or "metaphysically real" moral features of things. Call the positive ontological view that moral properties are instantiated in the world moral realism, and the negative ontological view that moral properties are not instantiated in the world moral anti-realism. This thesis is a statement of moral anti-realism because it holds that there are no instantiated moral properties, that moral properties like moral rightness, wrongness, goodness, and badness are not instantiated in the world. ${ }^{3}$

(2) is a psychological thesis about moral judgements. It is a statement of what is often called metaethical cognitivism because it holds that moral judgements are beliefs that ascribe

\footnotetext{
${ }^{1}$ Note that I do not define 'God' as a morally good being, because I am going to challenge the idea that God must be morally good. I am going to argue that a being who is not morally good could count or qualify as God.

2 These theses broadly accord with Bart Streumer's characterisation of normative error theory, see Bart Streumer, Unbelievable Errors: An Error Theory About All Normative Judgements (Oxford University Press, 2017). But note that I am concerned with the more narrow view of moral error theory, so I have characterised these theses in moral rather than normative terms. I am not here interested in the question of whether theism is compatible with normative error theory.

${ }^{3}$ Depending on one's views about the metaphysics of properties, one may wish to distinguish between the claims 'There are no moral properties' and 'There are no instantiated moral properties'. I make no such distinction in this paper. I use these claims interchangeably. Note also that while I characterise moral antirealism as the view that there are no moral properties, some philosophers characterise moral anti-realism as the view that there are no mind-independent moral properties. I do not follow these philosophers. I take moral antirealism to be the view that there are no moral properties, whether mind-dependent or mind-independent.
} 
moral properties. For example, the moral judgement that $\mathrm{X}$ is good is the belief that $\mathrm{X}$ is good, and this belief ascribes the moral property of being good to $\mathrm{X}$.

(3) is a semantic thesis about what it takes for a belief to be false. It holds that if a belief ascribes a property to an object that the object does not have, then the belief is false. This thesis is what gets us from (1) and (2) to moral error theory: Moral judgements are beliefs that ascribe moral properties, but there are no moral properties, so all moral judgements are false. ${ }^{4}$

Finally, I should clarify what I mean by 'compatible' and 'incompatible'. As I use these terms, two views are 'compatible' if one can coherently accept both of them, and 'incompatible' otherwise. Thus, in considering whether theism and moral error theory are compatible, I am considering whether one can coherently accept both views.

In the following section, I state two reasons why it matters whether theism and moral error theory are compatible. I then outline the best argument for thinking that these views are incompatible in the section after that.

\section{Why Compatibility Matters}

The first reason why it matters whether theism and moral error theory are compatible is that it has important implications for weighing up the plausibility of these views. If theism and moral error theory are incompatible, then evidence for theism turns out to be evidence against moral error theory, and evidence for moral error theory turns out to be evidence against theism. This is important because it means that considerations that are typically thought to be irrelevant for weighing up the plausibility of these views turn out to be relevant: theological considerations turn out to be relevant for weighing up the plausibility of moral error theory, and metaethical considerations turn out to be relevant for weighing up the plausibility of theism.

The second reason why it matters whether these views are compatible is that a prevalent assumption in philosophy of religion is undermined if they are. The prevalent assumption is the claim that theism entails moral realism. This claim is widely held. William Lane Craig writes, for example, that "God's existence entails (and is entailed by) the existence of [objective] moral values."5 Graham Oppy also writes that "the traditional philosophical conception of God requires a commitment to moral realism."6 This claim is important because it features in several arguments in the philosophy of religion literature. For example, it features in Graham Oppy's moral argument against theism which he formulates as follows: Moral realism is a necessary consequence of traditional theism; moral realism is false; therefore, traditional theism is false. ${ }^{7}$ It also features in discussions of moral arguments for the existence of God, and discussions of theological approaches to morality. For example, Adams, Baggett and Walls, Copan, Craig, Linville, and Mavrodes all seem to assume in their discussions of moral arguments for the existence of God that theism entails moral realism. ${ }^{8}$

\footnotetext{
${ }^{4}$ Note that negative moral beliefs are not moral judgements according to moral error theory, because they do not ascribe moral properties. For example, the belief that $\mathrm{X}$ is not good is not a moral judgement, because it does not ascribe a moral property to X. It merely says that X lacks the moral property of being good. This belief is not therefore false, according to moral error theory. For further discussion, see Streumer, Unbelievable Errors: An Error Theory About All Normative Judgements, 107-8.

${ }^{5}$ William Lane Craig, “This Most Gruesome of Guests”, in Is Goodness Without God Good Enough?, ed. Robert K. Garcia and Nathan L. King (Rowman \& Littlefield, 2009), 171.

${ }^{6}$ Graham Oppy, “Is God Good by Definition?”, Religious Studies 28, no. 4 (1992), 467.

${ }^{7}$ Oppy, "Is God Good by Definition?", 467.

${ }^{8}$ Robert Merrihew Adams, "Moral Arguments For Theistic Belief”, in Rationality and Religious Belief, ed. C. F. Delaney (University of Notre Dame Press, 1979); David Baggett and Jerry L. Walls, God and Cosmos: Moral Truth and Human Meaning (Oxford University Press, 2016); Paul Copan, "The Moral Argument", in The
} 
And Adams, Baggett and Walls, Evans, Hare, Quinn, and Zagzebski all seem to assume in their book-length discussions of theological approaches to morality that theism entails moral realism. ${ }^{9}$ This assumption seems to be motivated by the thought that theism is incompatible with an anti-realist moral ontology, but none of these philosophers devote any discussion to the question of whether this thought is right. Thus, whether theism and moral error theory are compatible matters, because if they are compatible, then the motivation for a prevalent assumption in philosophy of religion is undermined.

\section{The Divine Goodness Argument}

Why think that theism and moral error theory are incompatible? I take the best argument to be the divine goodness argument. According to this argument, these views are incompatible because theism entails that God instantiates the moral property of being good, and moral error theory entails that God does not. The divine goodness argument can be formulated as the following reductio argument:

(P1) Theism is true. (For reductio)

(P2) Moral error theory is true. (For reductio)

(P3) If theism is true, then God instantiates the moral property of being good.

(P4) If moral error theory is true, then God does not instantiate the moral property of being good.

(C1) Therefore, God instantiates the moral property of being good and God does not instantiate the moral property of being good.

The divine goodness argument purports to show that theism and moral error theory are incompatible by showing that a contradiction arises if one accepts both views (P1 and P2). If the divine goodness argument is successful, then theism and moral error theory are incompatible: one can't coherently accept both views. Let's consider the argument's two substantial premises ( $\mathrm{P} 3$ and $\mathrm{P} 4)$ in reverse order.

According to (P4), moral error theory entails that God does not instantiate the moral property of being good. This premise is true because it is entailed by the first thesis of moral error theory. So (P4) should be accepted. But what about (P3)? This is the problematic premise of the divine goodness argument. According to it, theism entails that God instantiates the moral property of being good. Let's call this the 'theism-entails-goodness premise'.

In this paper, I argue that moral error theorists should reject the theism-entailsgoodness premise because the two best arguments for it either fail or fail if moral error theory is true. The conceptual argument claims that the theism-entails-goodness premise is true because it is a conceptual truth that God is morally good, while the argument from perfect being theology claims that the premise is true because God is the greatest possible being, and

Rationality of Theism, ed. Paul Copan and Paul K. Moser (Routledge, 2003); William Lane Craig, Reasonable Faith (Crossway, 2008), 172-83; Mark D. Linville, "The Moral Argument”, in The Blackwell Companion to Natural Theology, ed. William Lane Craig and J. P. Moreland (Wiley-Blackwell, 2009); George Mavrodes, "Religion and the Queerness of Morality", in Rationality, Religious Belief, and Moral Commitment: New Essays in the Philosophy of Religion, ed. William J. Wainwright and Robert Audi (Cornell University Press, 1986). Note that I am not saying that moral arguments try to show that theism entails moral realism. I am merely saying that some proponents of moral arguments seem to assume this in their discussions of these arguments.

${ }^{9}$ Robert Merrihew Adams, Finite and Infinite Goods: A Framework for Ethics (Oxford University Press, 1999); David Baggett and Jerry L. Walls, Good God: The Theistic Foundations of Morality (Oxford University Press, 2011); C. Stephen Evans, God and Moral Obligation (Oxford University Press, 2013); John Hare, God's Command (Oxford University Press, 2015); Philip L. Quinn, Divine Commands and Moral Requirements (Oxford University Press, 1978); Linda Trinkaus Zagzebski, Divine Motivation Theory (Cambridge University Press, 2004). 
the greatest possible being would be morally good. In section 4, I argue that the conceptual argument fails because it is not a conceptual truth that God is morally good. In section 5, I argue that the argument from perfect being theology fails if moral error theory is true, because if moral error theory is true, then the greatest possible being would not be morally good.

The upshot of this, I argue, is that moral error theorists should reject the theismentails-goodness premise. They should therefore reject the divine goodness argument. In section 6, I argue that it follows from this that the divine goodness argument fails to show that theism and moral error theory are incompatible. I then argue that since the divine goodness argument is the best argument for thinking that these views are incompatible, we should think that they are compatible. Let's begin by considering the conceptual argument.

\section{The Conceptual Argument}

The conceptual argument claims that the theism-entails-goodness premise is true because it is a conceptual truth that God is morally good. What should we make of this claim? It is noteworthy that many philosophers endorse the related claim that it is a conceptual truth that God is perfectly good. James Rachels writes, for example, that:

To bear the title 'God' ... a being must have certain qualifications. He must, for example, be all-powerful and perfectly good in addition to being perfectly wise. ${ }^{10}$

Richard Swinburne makes a similar claim, saying:

I take the proposition 'God exists' ... to be logically equivalent to 'there exists a person without a body (i.e. a spirit) who is eternal, is perfectly free, omnipotent, omniscient, perfectly good, and the creator all things. ${ }^{11}$

Proponents of the conceptual argument might attempt to argue that it is a conceptual truth that God is morally good by arguing that it is a conceptual truth that God is perfectly good, because perfect goodness entails moral goodness. But this attempt fails because it is not a conceptual truth that God is perfectly good. Consider Oppy's remarks on Swinburne's view:

I do not think that one ought to say that 'God exists' is logically equivalent to 'there exists a person without a body ...etc'. For, in saying this, one is committed to the view that if, for example, (i) there exists a person without a body who is eternal, perfectly free, omnipotent, omniscient, very (but not quite perfectly) good, and the creator of all things; but (ii) there is no person without a body who is eternal, perfectly free, omnipotent, omniscient, perfectly good, and the creator of all things, then God does not exist. This seems to be an odd view to take; in the circumstances described, it seems to me that it would be more natural to say that God does exist, but that he is not quite as we imagined him to be. ${ }^{12}$

Oppy's remarks reveal that we would count a being who is not perfectly good as God- the being who is very (but not quite perfectly) good. This suggests that it is not a conceptual truth that God is perfectly good. For if it were, then plausibly we would not count a being who is not perfectly good as God: our concept of God would rule out the possibility of such a being

\footnotetext{
10 James Rachels, “God and Human Attitudes", Religious Studies 7, no. 4 (1971), 333, emphasis added.

${ }^{11}$ Richard Swinburne, The Existence of God (Oxford University Press, 1979), 8, emphasis added.

12 Oppy, “Is God Good by Definition?”, 468.
} 
qualifying as God. The attempt to argue that it is a conceptual truth that God is morally good by arguing that it is a conceptual truth that God is perfectly good thus fails, because it is plausibly not a conceptual truth that God is perfectly good.

But proponents of the conceptual argument need not make the bold claim that it is a conceptual truth that God is perfectly good. They need only make the more modest claim that it is a conceptual truth that God is morally good. But is this more modest claim true? To see whether it is, we need to see whether we would count a being who is not morally good as God. We can do this by considering the following scenario:

There is a necessarily existing incorporeal being who is eternal, perfectly free, omnipotent, omniscient, and who created the universe and everything in it. This being sustains the universe from moment to moment. Moreover, this being is the object of religious worship, answers prayers, and occasionally performs miracles. This being also loves all created beings, is deeply concerned for their well-being, always tries to promote their well-being to the best of his ability, and so on.

Almost everyone, I take it, would say that if this scenario is actual, then God exists. In other words, almost everyone would count this being as God.

Now, let us add one further qualification to the scenario. Let us suppose that the world in which this being exists is one in which moral error theory is true. That is, let us suppose that this being is not morally good - despite the fact that he loves all created beings, is deeply concerned for their well-being, always tries to promote their well-being to the best of his ability, and so on-because the world in which this being exists is one in which there are no moral properties. We can add this qualification to the scenario as follows:

There is a necessarily existing incorporeal being who is eternal, perfectly free, omnipotent, omniscient, and who created the universe and everything in it. This being sustains the universe from moment to moment. Moreover, this being is the object of religious worship, answers prayers, and occasionally performs miracles. This being also loves all created beings, is deeply concerned for their well-being, always tries to promote their well-being to the best of his ability, and so on. But, because moral error theory is true, this being is not morally good.

Note that in saying that this being is not morally good, I am not saying that this being is morally bad or morally neutral. For moral badness and moral neutrality are moral properties, and we are to imagine this being existing in a world in which moral error theory is true - a world in which there are no moral properties. Note also that I am not claiming that this scenario is metaphysically possible, but only that it is conceptually possible.

Does the fact that this being is not morally good change our intuition that this being is God? No, I don't think so. Almost everyone, I take it, would still say that if this scenario is actual, then God exists. In other words, almost everyone would still count this being as God. For this being just seems to be God in a world in which moral error theory is true. ${ }^{13}$ This suggests that it is not a conceptual truth that God is morally good. For if it were, then plausibly we would not count a being who is not morally good as God: our concept of God would rule out the possibility of such a being qualifying as God. The conceptual argument thus fails, because it is plausibly not a conceptual truth that God is morally good.

\footnotetext{
${ }^{13}$ The intuition that this being is God receives further support when we reflect on our response to a hypothetical speaker who claims to believe that this being exists, but also claims to believe that God does not exist. We are inclined, I submit, to treat the speaker as using 'God' is some non-standard way. This is evidence that the being described in the scenario is God.
} 
One might object that this being is not God because it is a conceptual truth that God is worthy of worship, and only morally good beings are worthy of worship. ${ }^{14}$ But I deny that only morally good beings are worthy of worship. It seems to me that the being described in this scenario $i s$ worthy of worship, so we have a clear counterexample to the claim that only morally good beings are worthy of worship. One might reply that this being can't be worthy of worship, because being worthy of worship is a moral property and this being exists in a world in which there are no moral properties. But I retort that although being worthy of worship is a normative property, it is not a moral one. So this being can be worthy of worship, because this being exists in a world in which moral rather than normative error theory is true. This objection thus fails to show that the being in question is not God. It thus fails to undermine my argument that the conceptual argument fails. ${ }^{15}$

Let's consider the next argument for the theism-entails-goodness premise.

\section{The Argument From Perfect Being Theology}

The argument from perfect being theology employs the method of perfect being theologythe method that uses the claim that God is the greatest possible being to work out what properties God would have. This argument claims that the theism-entails-goodness premise is true because God is the greatest possible being, and the greatest possible being would instantiate the moral property of being good.

I will grant, for the sake of argument, that God is the greatest possible being because many theists take this claim to be true, and by granting it we can see whether moral error theory is compatible with this traditional form of theism.

The claim I will take issue with here is that the greatest possible being would instantiate the moral property of being good. This claim is tantamount to the claim that perfect being theology entails that God instantiates the moral property of being good. It is noteworthy that many philosophers endorse this claim. Thomas Morris writes, for example, that:

Standardly employed, perfect being theology issues in a conception of God as a necessarily existent being who has such properties as omnipotence, omniscience, perfect goodness, eternity, and aseity as essential properties. ${ }^{16}$

William Rowe makes a similar remark, saying:

God is thought of as the greatest possible being, the being than which none greater exists ... Quite naturally, then, God is taken to be a being whose goodness, knowledge, and power is such that it is ... impossible for any being, including God himself, to have a greater degree of goodness, knowledge, and power. ${ }^{17}$

\footnotetext{
14 See, for example, William Lane Craig, "A Reply to Objections”, in Does God Exist? The Craig-Flew Debate, ed. Stan W. Wallace (Ashgate, 2003), 173.

${ }^{15}$ For what it's worth, I deny that it is a conceptual truth that God is worthy of worship. It seems to me that a parallel argument could be constructed to show that being worthy of worship is not part of our concept of God. This argument would proceed by showing that our intuition that a being counts as God is not changed when we stipulate that the being in question exists in a world in which normative error theory is true - a world in which there are no normative properties, and so a world in which no beings are worthy, or unworthy, of being worshipped, despite their having descriptive properties that would, in worlds in which normative realism is true, ground the normative property of being worthy of worship.

16 Thomas Morris, "Perfect Being Theology", Noûs 21, no. 1 (1987), 25, emphasis added.

17 William L. Rowe, Can God Be Free? (Oxford University Press, 2004), 1, second emphasis added.
} 
But whether the greatest possible being would be morally good depends on whether moral goodness is an impossible property, because if moral goodness is an impossible property, then not even the greatest possible being would be morally good, because possible beings can't instantiate impossible properties. ${ }^{18}$

The argument from perfect being theology thus fails if moral properties are impossible, because if they are, then the greatest possible being would not be morally good. In what follows, I argue that moral error theory implies that moral properties are impossible. I thus argue that the argument from perfect being theology fails if moral error theory is true.

The consensus view among contemporary moral error theorists is that moral error theory implies that moral properties are impossible. As Jonas Olson writes:

Most moral error theorists maintain that moral properties are necessarily uninstantiated [because] they are simply too queer to be instantiated in any possible world. A more theoretically motivated reason for this view is that moral facts, e.g., that inflicting pain is pro tanto morally wrong, would be necessary facts. But since there are no such facts in the actual world, there is no possible world in which there are moral facts. Correlatively, there is no possible world in which moral properties are instantiated. ${ }^{19}$

Call this the modal argument for the claim that if moral error theory is true, then moral properties are impossible. The modal argument can be formulated as follows:

(P5) If moral error theory is true, then there are no moral truths in the actual world.

(P6) If there are no moral truths in the actual world, then there are no moral truths in any possible world.

(P7) If there are no moral truths in any possible world, then there are no moral properties in any possible world.

(C2) Therefore, if moral error theory is true, then there are no moral properties in any possible world - that is, moral properties are impossible.

Let's consider the modal argument's premises.

According to (P5), if moral error theory is true, then there are no moral truths in the actual world. This claim is true because if moral error theory is true, then all moral

\footnotetext{
18 There is an objection to the claim that God is the greatest possible being that should be mentioned. The objection is this. Suppose that we have radically overestimated how great beings can be, and that Michael Jordan is, in fact, the greatest possible being - it's metaphysically impossible for any being to be greater than Michael Jordan. Clearly, the objection goes, we should not conclude that Michael Jordan is God. We should conclude instead that God does not exist. What this objection shows, as Jeff Speaks notes, is that "the claim that God is the greatest possible being does not capture [our core concept] of God. At best, it capture[s] ... our conception of God only [when] combined with certain theses about modal space," see Jeff Speaks, "Permissible Tinkering with the Concept of God", Topoi 36 (2017), 593. Why do I mention this objection? Because one might raise a similar objection here. One might object that if moral goodness is an impossible property, then modal space is too cramped for the claim that God is the greatest possible being to capture our concept of God. But this is not true. The reason why Michael Jordan does not count as God, even if he is the greatest possible being, is that our concept of God rules out finite beings like Michael Jordan from qualifying as God. But, as I have already argued, our concept of God does not rule out beings who are not morally good from qualifying as God. So even if moral goodness is an impossible property, the greatest possible being could still qualify as God, because not being morally good is conceptually compatible with being God.

${ }^{19}$ Jonas Olson, Moral Error Theory: History, Critique, Defence (Oxford University Press, 2014), 12-13, footnote 17 .
} 
judgements are false in the actual world, and so there are no moral truths in the actual world. $^{20}$

According to (P6), if there are no moral truths in the actual world, then there are no moral truths in any possible world. This claim is true because moral truths are putative necessary truths. In other words, they are such that if they obtain in one possible world, they obtain in all possible worlds, and if they don't obtain in one possible world, they don't obtain in any possible world. It follows from this that if there are no moral truths in the actual world, then there are no moral truths in any possible world.

According to (P7), if there are no moral truths in any possible world, then there are no moral properties in any possible world. This premise is true because moral properties entail moral truths. In other words, any world in which there is an instantiated moral property is a world in which there is at least one moral truth - for any instantiated moral property in world $w$, there is at least one moral truth in $w$ about that instantiated moral property. Consequently, if there are no moral truths in any possible world, then there are no moral properties in any possible world.

There are two objections that might be raised in response to the modal argument. The first objection states that it's not the case that all moral truths are necessary truths, because some moral truths are contingent truths. This objection seeks to undermine the following premise:

(P6) If there are no moral truths in the actual world, then there are no moral truths in any possible world.

This objection states that we should reject (P6) because the inference from the claim that there are no moral truths in the actual world to the claim that there are no moral truths in any possible world is licenced only if all moral truths are necessary truths - that is, only if all moral truths are such that if they don't obtain in one possible world, they don't obtain in any possible world. Given that some moral truths are contingent truths, (P6) should be rejected.

That some moral truths are contingent truths is undeniable. Consider the moral truth that I'm obligated to look after my pet cat. This moral truth is a contingent truth, because I might not have had this obligation. I might not have had a cat. In that case, I would not have had the obligation to look after my pet cat, and so it is only contingently true that I have this obligation.

The best response to this first objection is, I think, to deny that the inference in question is licenced only if all moral truths are necessary truths. One can point out that if there can be contingent moral truths only if there are necessary moral truths, then the inference from the claim that there are no moral truths in the actual world to the claim that there are no moral truths in any possible world is licenced. For if there are no moral truths in the actual world - and so there are no necessary moral truths - and there can be contingent moral truths only if there are necessary moral truths, then it follows that there are no necessary or contingent moral truths in any possible world.

The claim that there can be contingent moral truths only if there are necessary moral truths is plausible. As Erik Wielenberg writes:

[S] uppose that I promise to meet you for lunch on a certain occasion. Also suppose that on the occasion in question I have no sufficiently weighty reason not to keep my promise. It follows that I am obligated to meet you for lunch. This is an ethical truth,

\footnotetext{
${ }^{20}$ By 'moral truths' here, I mean atomic or simple moral truths, such as that inflicting pain is morally wrong, that helping others is morally good, and that being kind is morally permissible.
} 
yet it is a contingent truth. ... It seems to me that contingent ethical truths like these are always partly grounded in some necessary ethical truth (or truths). In this case, the relevant truth is something like, "It is morally wrong to fail to keep a promise unless you have some sufficiently weighty reason for doing so." 21

If Wielenberg is right and contingent moral truths are always partly grounded in necessary moral truths, then there can be contingent moral truths only if there are necessary moral truths. But why think that contingent moral truths are always partly grounded in necessary moral truths? One plausible reason is this: If contingent moral truths aren't always grounded in necessary moral truths, then it is inexplicable why contingent moral truths obtain. Take Wielenberg's example. Suppose that I promise to meet you for lunch, and that I have no sufficiently weighty reason not to keep my promise. Suppose then that the contingent moral truth "I'm obligated to meet you for lunch" obtains. What explains why this contingent moral truth obtains? Clearly, the necessary moral truth "It is morally wrong to fail to keep a promise unless you have some sufficiently weighty reason for doing so" would explain why this contingent moral truth obtains. But what if this contingent moral truth isn't grounded in any necessary moral truth? What then would explain why it obtains? It seems that nothing would explain why it obtains. It would simply be a brute contingent moral truth that the combination of my promising to meet you for lunch and my having no sufficiently weighty reason not to keep my promise makes it the case that I'm obligated to meet you for lunch. ${ }^{22}$ Since a commitment to brute contingent moral truths counts significantly against a view, we should accept the claim that contingent moral truths are always partly grounded in necessary moral truths, and so accept that there can be contingent moral truths only if there are necessary moral truths. The first objection to the modal argument can thus be resisted.

The second objection to the modal argument states that theists should reject (P6) because God is omnipotent, and so even if there are no moral truths in the actual world, it doesn't follow that there are no moral truths in any possible world, because God qua omnipotent being could make any moral truth obtain.

There are two related reasons why we should resist this line of thought. First, it implies that no moral truths are necessary truths. For if there are no moral truths in the actual world, but God exists and could make any moral truth obtain, then it follows that no moral truths are necessary truths - that is, no moral truths are such that if they obtain in one possible world, they obtain in all possible worlds, and if they don't obtain in one possible world, they don't obtain in any possible world. This implication seems implausible to most moral philosophers.

Second, it implies that God has objectionable control over morality. For if there are no moral truths in the actual world, but God exists and could make any moral truth obtain, then God has the power to make moral error theory false when it is true. But if this is right,

${ }^{21}$ Erik J. Wielenberg, Value and Virtue in a Godless Universe (Cambridge University Press, 2005), 52.

${ }^{22}$ One might object that if the moral truth "It is morally wrong to fail to keep a promise unless you have some sufficiently weighty reason for doing so" were a contingent moral truth, then we would have an explanation of why the contingent moral truth "I'm obligated to meet you for lunch" obtains that isn't grounded in any necessary moral truth. But it seems implausible to suppose that moral principles like "It is morally wrong to fail to keep a promise unless you have some sufficiently weighty reason for doing so" are contingent moral truths. Most moral philosophers take moral principles to be necessary moral truths. Gideon Rosen has recently challenged this orthodox view, but it is beyond the scope of this paper to discuss the issues he raises, see Gideon Rosen, "What Is Normative Necessity?", in Metaphysics, Meaning, and Modality: Themes from Kit Fine, ed. Mircea Dumitru (Oxford University Press, 2020). For further discussion, see James Dreier, "Is There a Supervenience Problem for Robust Moral Realism?", Philosophical Studies 176 (2019); Pekka Väyrynen, "The Supervenience Challenge to Non-Naturalism", in The Routledge Handbook to Metaethics, ed. Tristram McPherson and David Plunkett (Routledge, 2017). 
then it presumably follows that God has the power to make moral error theory true when it is false. This would mean that God has the power to make any true moral judgement false. Most philosophers, theist and non-theist alike, think that not even an omnipotent being would have this sort of power. ${ }^{23}$ So we should resist the second objection to the modal argument. ${ }^{24}$

The modal argument thus withstands the two objections that might be raised in response to it. We can thus conclude that if moral error theory is true, then moral properties are impossible. Moral error theorists should thus reject the argument from perfect being theology, because if moral error theory is true, then moral properties are impossible, and if moral properties are impossible, then the greatest possible being would not be morally good.

In the final section, I argue that theism and moral error theory are compatible because moral error theorists should reject the divine goodness argument.

\section{Theism and Moral Error Theory are Compatible}

To recap the argument so far, moral error theorists should reject the divine goodness argument because the two best arguments for the theism-entails-goodness premise either fail or fail if moral error theory is true. The conceptual argument fails because it is not a conceptual truth that God is morally good. And the argument from perfect being theology fails if moral error theory is true, because if moral error theory is true, then the greatest possible being would not be morally good. Moral error theorists should thus reject the theism-entails-goodness premise. They should therefore reject the divine goodness argument.

The upshot of this is that the divine goodness argument fails to show that theism and moral error theory are incompatible - it fails to show that it is incoherent to accept both views. We can see this by considering the following case. Suppose that A accepts both theism and moral error theory, and that B tries to show that A is being incoherent. B presents the divine goodness argument to show that $\mathrm{A}$ is being incoherent. But $\mathrm{A}$ can reject the divine goodness argument because A can reject the theism-entails-goodness premise. B has thus failed to show that $\mathrm{A}$ is being incoherent. The divine goodness argument thus fails to show that theism and moral error theory are incompatible.

If the divine goodness argument is the best argument for thinking that theism and moral error theory are incompatible, then we should think that these views are compatible. For if the best argument for thinking that two views are incompatible fails, then we shouldn't think that those two views are incompatible. We should think instead that they are compatible. In what follows, I argue that the divine goodness argument is the best argument for thinking that these views are incompatible. I argue for this by eliminating alternatives. ${ }^{25}$

\footnotetext{
${ }^{23}$ See, for example, Wielenberg, Value and Virtue in a Godless Universe, 41-2.

${ }^{24}$ Note that I am not claiming that omnipotence entails the power to make any moral truth obtain. For I am claiming that theists should reject this claim. Note also that while some philosophers, like divine command theorists, think that God could make some moral truths obtain even if they do not obtain in the actual world, these philosophers typically think that God can only do this if there are already moral truths in the actual world. For example, if there are moral truths like "It is morally obligatory to obey God's commands" or "To be morally obligatory just is to be divinely commanded" in the actual world. Since the issue at stake is whether God could make moral truths obtain if there are no moral truths in the actual world, it's not clear to me that appealing to divine command theory would help proponents of the second objection support their claim that God could make such truths obtain if there are no moral truths in the actual world.

${ }^{25}$ Note that I claim that if the best argument for thinking that two views are incompatible fails, then we should think that those views are compatible. This is because we should think that two views are compatible unless there are good arguments or reasons for thinking that they are incompatible, and it is clear that if the best argument for thinking that two views are incompatible fails, then there are no good arguments or reasons for thinking that those views are incompatible. (For if there were such arguments, then those arguments would, per impossibile, be better than the best argument.) Since I argue that the divine goodness argument is the best argument for thinking that theism and moral error theory are incompatible, and this argument fails, I conclude that there are no good arguments or reasons for thinking that theism and moral error theory are incompatible,
} 
As far as I can see, there are only three alternative arguments for thinking that theism and moral error theory are incompatible. The first argument is the argument that theism and moral error theory are incompatible because theism entails that God instantiates some moral property other than goodness.

But this argument is no better than the divine goodness argument, because substituting moral goodness with some other moral property does not result in any kind of improvement. For the two best arguments for the theism-entails-some-other-moral-property premise are modified versions of the conceptual argument and the argument from perfect being theology, and these arguments are subject to the same problems as the original conceptual argument and argument from perfect being theology. This argument thus fails to undermine the divine goodness argument's claim to be the best argument.

The second argument is the argument that theism and moral error theory are incompatible because the motivation for these views is incompatible: arguments for moral error theory are arguments against theism, and vice versa.

But this argument fails to show that these views are incompatible, because even if the motivation for these views were incompatible, that would not show that theism and moral error theory are incompatible. It would only show that one shouldn't accept one view if one accepts arguments for the other. And that is a far cry from showing that the views themselves are incompatible, that one can't coherently accept both views. This argument thus fails to undermine the divine goodness argument's claim to be the best argument.

The third and final argument is the argument that theism and moral error theory are incompatible because moral properties are identical with, or constituted by, divine properties. One formulation of divine command theory holds that moral obligations are constituted by divine commands. If this theory is true and God issues some commands, the argument goes, then theism and moral error theory are incompatible: one can't coherently accept both views.

But this argument fails to show that theism and moral error theory are incompatible, because divine command theory has no bearing on whether one can coherently accept theism and moral error theory. Of course, if divine command theory is true and God issues some commands, then moral obligations obtain, and so moral error theory is false. But that doesn't show that one can't coherently accept theism and moral error theory. It only shows that one can't coherently accept theism, divine command theory, the claim that God issues some commands, and moral error theory. Clearly, if one couldn't coherently accept theism without also accepting divine command theory and the claim that God issues some commands, then theism and moral error theory would be incompatible. But that is not the case: one can coherently accept theism without accepting divine command theory and the claim that God issues some commands. This argument thus fails to show that theism and moral error theory themselves are incompatible. It thus fails to undermine the divine goodness argument's claim to be the best argument. ${ }^{26}$

and so conclude that we should think they are compatible. Thanks to an anonymous referee for pressing me on this point.

${ }^{26}$ Note that even if divine command theory and the claim that God issues some commands were necessarily true - true in all metaphysically possible worlds - that would not undermine my argument. For I have not argued for the bold claim that there is a metaphysically possible world in which both theism and moral error theory are true. I have only argued for the more modest claim that one can coherently accept both views. It should be noted, however, that if conceptual divine command theory were true and the concept of being obligatory were identical to that of being commanded by God, then these views would be incompatible in the sense of its being incoherent to accept both views. But conceptual divine command theory is not plausible, and no contemporary divine command theorist that I know of currently argues for it. For further discussion, see Robert Merrihew Adams, "A Modified Divine Command Theory Of Ethical Wrongness", in Religion and Morality, ed. Gene Outka and John Reeder (Anchor, 1973); Robert Merrihew Adams, "Divine Command Metaethics Modified Again”, Journal of Religious Ethics 7, no. 1 (1979); Baggett and Walls, Good God: The 
Consequently, we can conclude that the divine goodness argument is the best argument for thinking that theism and moral error theory are incompatible. We can thus conclude that we should think that theism and moral error theory are compatible.

\section{Conclusion}

In this paper, I articulated the best argument for thinking that theism and moral error theory are incompatible - the divine goodness argument. I argued that the divine goodness argument fails to show that theism and moral error theory are incompatible and that we should, as a result, think that these views are compatible. The implications of this striking conclusion are as follows: (i) we shouldn't think that the plausibility of theism is relevant for weighing up the plausibility of moral error theory, nor vice versa, and (ii) we shouldn't think that theism entails moral realism because the motivation for this assumption - that theism is incompatible with an anti-realist moral ontology-is undermined by this paper's conclusion. ${ }^{27}$

\section{Bibliography}

Adams, Robert Merrihew. 1973. “A Modified Divine Command Theory Of Ethical Wrongness". In Religion and Morality, edited by Gene Outka and John Reeder, 31847. New York: Anchor. 1979. "Divine Command Metaethics Modified Again”. Journal of Religious Ethics 7, no. 1: 66-79.

- 1979. "Moral Arguments For Theistic Belief". In Rationality and Religious Belief, edited by C. F. Delaney, 116-40. Notre Dame: University of Notre Dame Press. 1999. Finite and Infinite Goods: A Framework for Ethics. Oxford: Oxford University Press.

Baggett, David, and Jerry L. Walls. 2011. Good God: The Theistic Foundations of Morality. Oxford: Oxford University Press.

- 2016. God and Cosmos: Moral Truth and Human Meaning. Oxford: Oxford University Press.

Copan, Paul. 2003. "The Moral Argument". In The Rationality of Theism, edited by Paul Copan and Paul K. Moser, 149-74. London: Routledge.

Craig, William Lane. 2003. "A Reply to Objections". In Does God Exist? The Craig-Flew Debate, edited by Stan W. Wallace, 155-88. Aldershot: Ashgate.

2008. Reasonable Faith. Wheaton: Crossway.

2009. "This Most Gruesome of Guests". In Is Goodness Without God Good

Enough?, edited by Robert K. Garcia and Nathan L. King, 167-88. Lanham: Rowman \& Littlefield.

Dreier, James. 2019. "Is There a Supervenience Problem for Robust Moral Realism?" Philosophical Studies 176: 1391-1408. https://doi.org/10.1007/s11098-019-01244-w. Evans, C. Stephen. 2013. God and Moral Obligation. Oxford: Oxford University Press. Hare, John. 2015. God's Command. Oxford: Oxford University Press.

Theistic Foundations of Morality, 111-19; Mark C. Murphy, An Essay on Divine Authority (Cornell University Press, 2002), 77-82.

${ }^{27}$ I am very grateful to Alex Gregory, Brad Hooker, Martin Dunkley Smith, Jonathan Way, and two anonymous referees for this journal for helpful comments on earlier drafts of this paper. I am also grateful to members of the Post-Graduate Research Seminar at the University of Southampton, and to participants of the 14th Open Minds conference at the University of Manchester, and the 5th Theistic Ethics Workshop at Georgetown University for insightful feedback. This work was generously supported by the Arts and Humanities Research Council [AH/L503939/1]. 
Linville, Mark D. 2009. "The Moral Argument". In The Blackwell Companion to Natural Theology, edited by William Lane Craig and J. P. Moreland, 391-448. Oxford: Wiley-Blackwell.

Mavrodes, George. 1986. "Religion and the Queerness of Morality". In Rationality, Religious Belief, and Moral Commitment: New Essays in the Philosophy of Religion, edited by William J. Wainwright and Robert Audi, 213-26. Ithaca: Cornell University Press.

Morris, Thomas. 1987. "Perfect Being Theology". Noûs 21, no. 1: 19-30.

Murphy, Mark C. 2002. An Essay on Divine Authority. Ithaca: Cornell University Press.

Olson, Jonas. 2014. Moral Error Theory: History, Critique, Defence. Oxford: Oxford University Press.

Oppy, Graham. 1992. “Is God Good by Definition?” Religious Studies 28, no. 4: 467-74. https://doi.org/10.1017/S0034412500021867.

Quinn, Philip L. 1978. Divine Commands and Moral Requirements. Oxford: Oxford University Press.

Rachels, James. 1971. "God and Human Attitudes". Religious Studies 7, no. 4: 325-37. https://doi.org/10.1017/S0034412500000391.

Rosen, Gideon. 2020. "What Is Normative Necessity?” In Metaphysics, Meaning, and Modality: Themes from Kit Fine, edited by Mircea Dumitru, 205-33. Oxford: Oxford University Press.

Rowe, William L. 2004. Can God Be Free? Oxford: Oxford University Press.

Speaks, Jeff. 2017. "Permissible Tinkering with the Concept of God". Topoi 36: 587-97. https://doi.org/10.1007/s11245-016-9387-y.

Streumer, Bart. 2017. Unbelievable Errors: An Error Theory About All Normative Judgements. Oxford: Oxford University Press.

Swinburne, Richard. 1979. The Existence of God. Oxford: Oxford University Press.

Väyrynen, Pekka. 2017. "The Supervenience Challenge to Non-Naturalism”. In The Routledge Handbook to Metaethics, edited by Tristram McPherson and David Plunkett, 170-84. New York: Routledge.

Wielenberg, Erik J. 2005. Value and Virtue in a Godless Universe. Cambridge: Cambridge University Press.

Zagzebski, Linda Trinkaus. 2004. Divine Motivation Theory. Cambridge: Cambridge University Press. 